\title{
A Fossil Gymnospermous Leaf Gnetalophyllum deccanii gen. et sp.nov. From The Deccan Intertrappean Beds of Mohgaonkalan, M.P., India
}

\author{
S.D.Narkhede ${ }^{1}$, A.S.Khursel ${ }^{2}$ \\ I'Department of BotanyGovernment Science College, Gadchiroli,(MS) India) \\ ${ }^{2}$ (Department of Botany,Shankarlal Agrawal Science College, Salekasa, District Gondia, (MS)India)
}

\begin{abstract}
Mohagaonkalan is the well known locality of the Deccan intertrappean series of Chhindwara district, of Madhya pradesh belonging to upper most cretaceous period. The present fossil leaf Gnetalophyllum deccanii collected from the deccan Intertrappean beds of Mohgaonkalan. The leaf is Gymnospermous, triangular in shape with ridges and furrows. Mesophyll undifferentiated, transfusion tissues are totally absent and vascular tissue present in radiating arm fashion. On comparison it shows close affinities with the order Gnetales. It measures 3099um in length along with lamina and $1433 \mu \mathrm{m}$ in width in the median region were as $1033 \mu \mathrm{m}$ in the laminar region.
\end{abstract}

Keywords: Deccan, Gymnospermic, Intertrappean, Mesophyll,Triangular.

Submitted Date 31 May 2013

Accepted Date: 06 June 2013

\section{Introduction}

The present investigation deals with the anatomical details of petrified gymnospermous leaf from the Deccan Intertrappean beds of Mohgaonkalan M.P.,India.So far many Dicotyledonous leaves have been reported from this region but very few gymnospermous leaves have been reported from these beds. These are Gymnospermophyllum cycadense (Kapgate, 1982), Cycadophyllum decanii (Kumar, 1984) and Ramanujamophyllum cycadii (Narkhede\&Qurashi, 2004) are the Gymnosperm leaf specimen described so far from this same locality.

\section{Material and Method}

The present fossil specimen was present in a black chert.It was exposed in transverse plane on breaking the chert. This was studied anatomically by taking serial peel sections. These were studied further under the microscope and camera lucida sketches were drawn.

\section{Description}

In transverse plane, leaf appears triangular in shape with ridges and furrows. It measures $3099 \mu \mathrm{m}$ in length along with lamina and $1433 \mu \mathrm{m}$ in width in the median region where as $1033 \mu \mathrm{m}$ in the laminar region. A thick cuticle layer is present on the upper and lower epidermis of the present fossil leaf. Mesophyll tissue is undifferentiated and vascular bundles are well preserved in radiating arm fashion from median to midrib without bundle sheath. (Plate: I, Fig1; Text Fig: 1.).The anatomical details are as follows.

1.1 Cuticle: Thick cuticle is present on both the upper and lower surface of leaf (Plate: I, Fig1.)

1.2 Epidermis: A well preserved epidermis shows presence of ridges and furrows on both the upper and lower surface of present leaf (Plate: I, Figs.1, 2.3)It is made up of compactly arranged elongated parenchymatous cells. The epidermal cell measures $33.33 \mu \mathrm{m}$ to $49.99 \mu \mathrm{m}$ in size. Both the upper and epidermal cells are similar in structure. Sunken stomata's are seen mostly below every ridge (Plate: I, Figs. $2 \& 3$ ).

1.3 Hypodermis:-Below epidermis hypodermis is present. It consists of 1 to 2 layers of thick walled parenchymatous cells in both median and laminar region. The hypodermal cells measures $41.66 \mu \mathrm{m}$ to $66.66 \mu \mathrm{m}$ in size. ( Plate: I, Fig :2,3,4).

1.4 Mesophyll: Just below the hypodermal region mesophyll tissue is present. The mesophyll tissue is undifferentiated i.e. not differentiated into palisade and spongy parenchyma. It consists of thick walled sclerenchymatous cells with intercellular spaces. Each cell is rounded to circular in shape and measures $49.99 \mu \mathrm{m}$ to66.66 $\mu \mathrm{m}$ in size. (Plate: I, Fig. 5).

1.5 Transfusion tissues: It is totally absent in the present fossil leaf. 
1.6 Vascular tissue: A well preserved vascular bundle present in a radiating arm fashion. It runs radially from median to margin. The vascular elements are not enclosed in a bundle sheath. The xylem and phloem present on the same radius alternating with each other (Plate: I, Figs. $3 \&$ 4.)

1.7 Xylem: The xylem element are very well preserved, metaxylem and Protoxylem are placed radially followed by phloem. Metaxylem Measures $133 \mu \mathrm{m}$ to $99.9 \mu \mathrm{m}$ in size and protoxylem measures $90 \mu \mathrm{m}$ to $66.6 \mu \mathrm{m}$ in size. (Plate: I, Fig. 4).

1.8 Phloem: It is well preserved, present in a radiating arm after 4 to 6 xylem Vessels. The phloem measures $40.33 \mu \mathrm{m}$ to $33.33 \mu \mathrm{m}$ in size and consisting of phloem parenchyma. (Plate: I, Figs. 2, 3, 4).

\section{Identification}

On the basis of anatomical study of present fossil leaf, some outstanding characters observed which are used to identify it like triangular leaf showing presence of ridges and furrows. Thick cuticle present on both the surfaces of leaf,stomatas sunken. Hypodermis present.Mesophyll undifferentiated and made up of sclerenchymatous cells with intercellular spaces. Transfusion tissues totally absent. Vascular tissues present in the radiating arm fashion.Metaxylem \& protoxylem placed radially followed by phloem. Bundle sheath absent.

\section{Discussion}

On the basis of the above mentioned anatomical details it is quite in order to surmise that the specimen shows Xerophytic nature of Gymnospermous leaf hence it is compared with earlier reported fossil Gymnosperm leaves from the same locality for its identification.

The earlier described fossil Gymnospermous leaves from Deccan Intertrappean beds of India differ from the present leaf in a number of characters.

The Gymnospermophyllum cycadense (Kapgate 1982), differ from the present leaf in having, differentiated mesophyll, presence of transfusion tissue and arrangrment of vascular elements.

Whereas, Cycadophyllum decanii (Kumar 1984), vary from the present leaf in having, large median vascular bundle, absence of hypodermis and absence of stomata.

Similarly, in Ramanujamophyllum cycadii (Qurashi 2003), the difference encountered from the present leaf in having, thick sclernchymatous hypodermal region, presence of transfusion tissue and absence of ridges \& furrows in the epidermal region which is a unique features of present fossil leaf.

Thus, no close affinities were observed between the earlier described fossil Gymnosperm leaves with the present one.

Now, comparison of the present leaf with the living one helps in identification. Arnold (1948) has proposed a classification of Gymnosperms into three major divisions: Chlamydospermophyta, Cycadophyta and Coniferophyta.Comparison of present fossil leaf with three major divisions of Gymnosperms. Chlamydospermophyta resembles in having undifferentiated mesophyll tissue and presence of stomata, but differ in having well developed hypodermis and arrangement of vascular tissue which is well preserved in present leaf. Cycadophyta resembles the present leaf in having well developed thick walled cuticular epidermis and presence of hypodermis but differ greatly in respect of undifferentiated mesophyll tissue, vascular tissue and absence of transfusion tissue.Further, the present specimen is compared with Coniferophyta, it shows similarity in presence of triangular shape of leaf, thick cuticular epidermis, presence of hypodermis and sunken stomata. But difference occurs in having undifferentiated mesophyll tissue and absence of transfusion tissue.

However, the present leaf have its own unique feature of vascular element that is present in a radiating arm as an arc from median to both the side of margin without bundle sheath as well as triangular shape of leaf with presence of ridges and furrows. Thus, the above discussion gives an idea that the present fossil leaf shares many characters with member of Coniferophyta.

Coniferophyta (coniferopsida) further sub-divided into two major order i.e.; Coniferales and Gnetales. The present leaf shows one similarity with Coniferales, in having triangular shape of leaf. But vary in resin canals and transfusion tissue which is absent in fossil one. But shows greater affinities with the order Gnetales, in having triangular shape of leaf, thick cuticular epidermis, presence of hypodermis and sunken stomata and only varying in its own unique vascular element arrangement in a radiating arm manner and triangular shape of leaf with presence of ridges and furrows.

Order Gnetales, is further divided into single family Gnetaceae and most advanced genus (among Gymnosperm) is Gnetum. When the present leaf is compared with unique genus Gnetum it differs greatly in respect of mesophyll tissue differentiated into palisade and spongy parenchyma, presence of sclerenchyma and stone cells all these characters are totally absent in present fossil leaf.

Thus, on the basis of above discussion it has been concluded that the present fossil leaf shows close affinities with the family Gnetaceae but does not resemble with genera of family. Hence, can be placed under the family Gnetaceae and named as Gentalophyllum deccanii gen.et sp. nov. The generic name after the family Gnetaceae to which it shows greater affinities and specific name after the Deccan trap. 
Diagnosis

Gentalophyllum gen. nov

Leaf triangular in shape with ridges and furrows, thick cuticularised epidermis, hypodermis present, mesophyll undifferentiated and made up of sclerenchymatous cells with intercellular space, vascular element arranged in radiating arm fashion from median to margin of leaf and bundle sheath absent.

Gentalophyllum deccanii gen. et sp. nov

Triangular leaf with ridiges and furrows, it measures 3099um in length along with lamina and 1433um in width in the median region were as $1033 \mathrm{um}$ in the laminar region. Epidermis cuticularised parenchymatous, sunken stomata, mesophyll sclerenchymatous with intercellular space, transfusion tissue absent, vascular element arranged in radiating arm manner, metaxylem and protoxylem placed radially followed by phloem. Metaxylem measures $133 \mathrm{um}$ to $99.9 \mathrm{um}$ in size and protoxylem measures 90um to 66.6um in size. Phloem consist of phloem parenchyma and it measures 40.33um to 33.33um in size. Bundle sheath is absent.

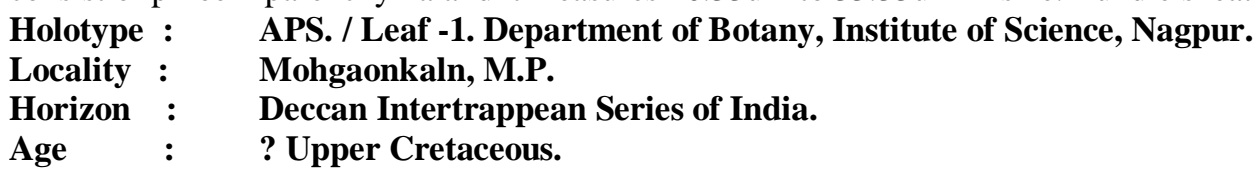

\section{References}

[1]. Arnold, C. A. (1948) Classification of Gymnosperms from the point of view of Palaeobotany. Bot. Gaz.,110; 2-12.

[2]. Kapgate, D. K. (1982) Study of Mega and Micro fossil flora from the Deccan Intertrappean series of India. Ph. D. Thesis, Nagpur University, Nagpur.

[3]. Kumar, A. S. (1984) Research on Deccan Intertrappean flora of india Ph. D. Thesis, Nagpur University, Nagpur.

[4]. Narkhede,S.D.\&Qurashi,S.P.(2004) A new petrified leaf from the Deccan Intertrappean beds of Mohgaonkalan, M.P.,India, Proc.National Sympo.Bioresources \&Bioenterprise pp.28-32.

Gnetalophyllum deccaniigen. et sp. nov

\section{EXPLANATION OF PLATE-I, FIGS. 1 To 5}

Fig. 1 : Transverse section shows triangular leaf and vascular elements present in radiating arm fashion. $50 \mathrm{X}$

Fig. 2 : $\quad$ Transverse section of leaf showing thick cuticular epidermis with suken stomata and undifferentiated mesophyll tissue. 100X

Fig. $3 \quad$ : $\quad$ Transverse section of leaf showing ridges and furrows on both the surface of leaf. $100 \mathrm{X}$

Fig. $4 \quad$ : $\quad$ Enlarged view showing metaxylem, protoxyllem and phloem. 100X

Fig. $5 \quad$ : $\quad$ Enlarged view of sclerenchymatous mesophyll tissue with intercellular space. 400X 


\section{PLATE-I}

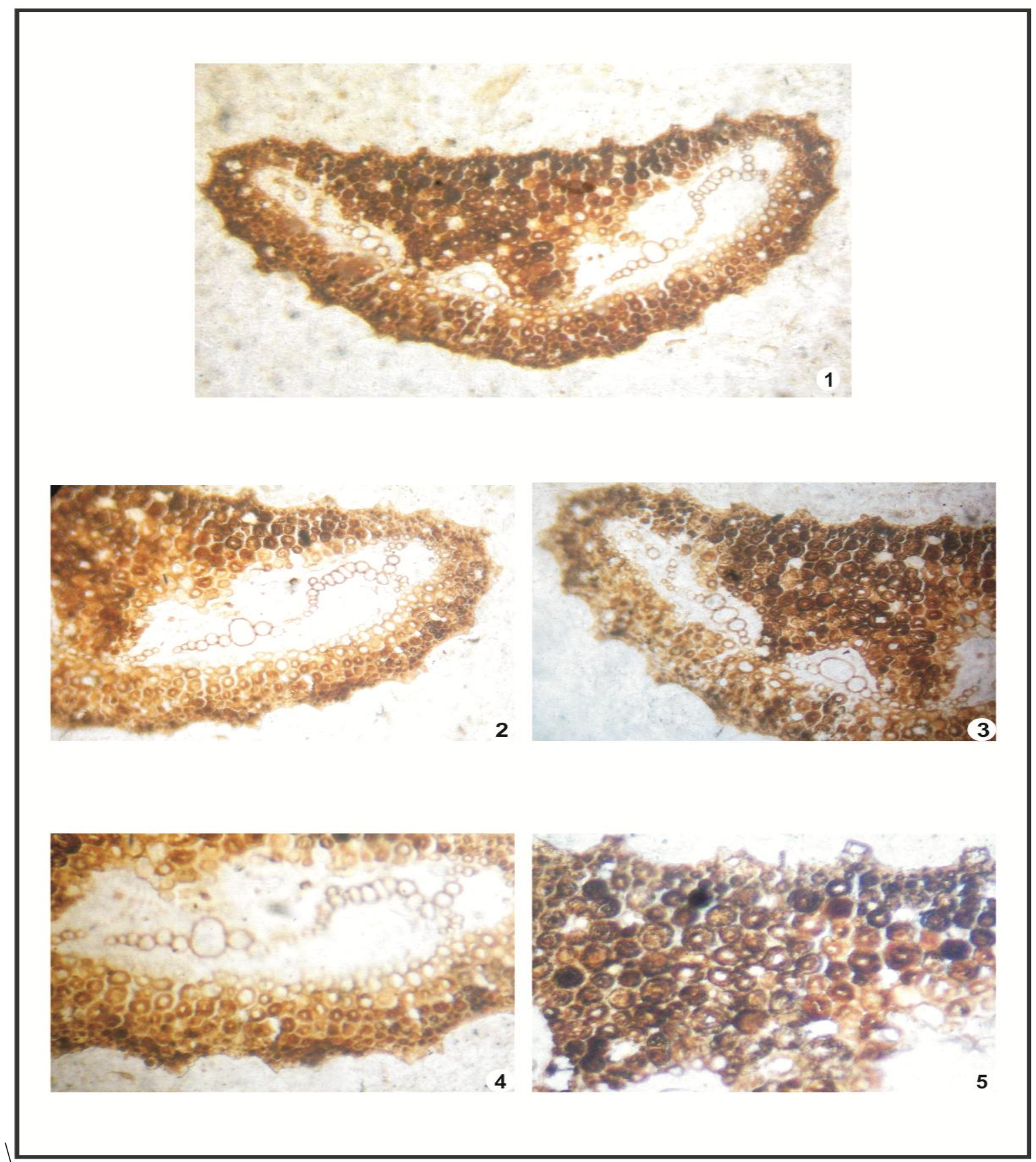

